\title{
Comment on "Present and Future of the British Schools, Institutes and Societies Abroad"
}

\author{
Sarah Finke \\ Associate Expert, Tangible Heritage Section, UNESCO Division of \\ Cultural Heritage
}

Dr Finlayson's lead article, written from an insider's perspective, gives an instructive and concise overview of the present activities, funding and management practices, as well as public and political relationships and future directions, of the 11 British Schools, Institutes and Societies abroad.

The article, which I read with great interest, provides valuable insight into the functioning of the different institutions in their respective environments, and characterises them as highly active research bodies covering a wide academic spectrum while maintaining a special focus and competence in the field of archaeology and surveying. The linkages between these institutions and academic networks in the UK are notable, underlining the close relationships maintained between the staff of these institutions and UK universities.

From my perspective, the portrayal of the public and political relationships of the institutions in their host countries is particularly interesting. According to the author, the institutions are not only centres of UK-based research with a special focus on archaeology, but multi-disciplinary centres covering significant scientific issues of the regions in which they are located and forming a close network, accessible to researchers of the host countries. However, I would also have been interested to see a brief description of the interaction between archaeology and other disciplines at the institutions.

Another aspect I would have valued in Dr Finlayson's otherwise comprehensive article is information on the distribution of funding within the institutions. With the geographical distribution of the institutions reflecting "a combination of traditional and contemporary understandings of our cultural, religious and scientific roots... and British Imperial and Commonwealth connections", an analysis of the distribution of funding within them would lead to useful insights on the prioritisation of these roots and connections today, further characterising the cultural and social role of these institutions in the intercultural dialogue.

The British Schools, Institutes and Societies abroad have established and maintain strong links to the local political institutions and civil society of the host countries, providing research infrastructures, library facilities and employment for local researchers. Additionally, they organise workshops, seminars and lectures. These services amount to a "tangible return" for the host countries, which, in my view, constitutes a substantial benefit for these, and is a crucial contributing factor to the significance of these institutions in both the present and the future, as well as to their relevance as vectors for social 
and cultural development. Through 'returning' access to research resources at the institutions, creating a platform for scientific debate and facilitating intercultural dialogue with representatives of the host countries, the institutions also make a substantial contribution to capacity-building and sharing of knowledge in developing countries.

These institutions provide yet another example of the key role culture has to play in sustainable development. Enhancing these linkages between culture and development is a strategic objective of UNESCO in the field of culture within the Organisation's medium-term strategy for the years 2002-2007 (UNESCO 2002: 42-43). The Organisation pursues its efforts to bolster cooperation in the domain of cultural heritage and to intensify efforts to harness national expertise and build capacities in heritage conservation and management, especially in the least-developed countries. Dr Finlayson's characterisation of the British institutions abroad as multi-disciplinary centres of research, knowledge sharing and dialogue confirms that UNESCO and these institutions have common goals and that a future partnership could therefore be envisaged.

In this context, I would like to provide examples of existing and fruitful cooperation between UNESCO and archaeological institutions, established particularly within the framework of the UNESCO/Japan Funds-in-Trust project for the safeguarding of the Bamiyan site in Afghanistan. The project for this world-renowned site, which housed the tallest standing Buddha statues in the world before their destruction in early 2001 and whose cultural landscape and archaeological remains were inscribed in 2003 on the World Heritage List, consists of major safeguarding activities. These include the emergency consolidation of the cliffs and niches of the Bamiyan Buddhas of AD 540 and AD 590; the preservation of mural paintings in the Buddhist caves, dating from the fifth to early ninth centuries $\mathrm{AD}$; the conservation of the Buddha statue fragments; and the creation of a Master Plan, documentation and archaeological activities. The National Research Institute for Cultural Properties in Tokyo, as well as an archaeological mission of the University of Strasbourg and the German University of Aachen, cooperate with Afghan experts, and provide training for Afghan archaeologists and employment for local community members.

Another partner archaeological institute for UNESCO projects in Afghanistan with similar development objectives is the Italian Istituto per l'Africa et l'Oriente (ISIAO). Since the looting of archaeological sites and the illicit trafficking of cultural property are urgent problems in contemporary Afghanistan, the Italian institute, in cooperation with UNESCO, carried out protective archaeological excavations at the World Heritage site of Jam (Ghur Province). In addition, a museum rehabilitation project is presently being implemented jointly by ISIAO and UNESCO in Ghazni (Ghazni Province), thanks to funds provided by the Italian Government. Since equipment and training constitute a major need for Afghan archaeologists and museum experts, UNESCO also coordinated the bilateral Afghan-British activity of installing a new restoration laboratory in the National Museum of Afghanistan in Kabul. The laboratory is funded by the British Museum and has been installed by the British contingent of the International Security Assistance Force in Afghanistan (ISAF). 
In the same spirit in which these projects have been implemented with close collaboration between UNESCO and partner agencies, cooperation between the Organisation and British Schools, Institutes and Societies abroad could be established in developing countries, notably in post-conflict or conflict situations such as Afghanistan or Iraq. In such situations, cultural heritage may become a symbolic target of aggression, incomprehension and rejection, but it can also play a role in uniting former enemies due to its symbolic value for different parties, and in the process serve as a tool for reconciliation and peace.

\section{Reference}

UNESCO 2002. United Nations Educational, Scientific and Cultural Organization, Medium-Term Strategy 2002-2007: Contributing to Peace and Human Development in an Era of Globalization Through Education, the Sciences, Culture and Communication. Paris: UNESCO. [http://unesdoc.unesco.org/images/0012/001254/ 125434 e.pdf?DocCode $=31 \% 20 \mathrm{C} /$ 4\%20APPROVED] [Accessed November 2005]. 